\title{
A new direction for water management? Indigenous nation building as a strategy for river health
}

\author{
$\underline{\text { Steve Hemming }}^{1}, \underline{\text { Daryle Rignev }}^{1}, \underline{\text { Samantha L. Muller }}^{1}$, Grant Rignev $^{2}{ }^{2}$ and $\underline{\text { Isobelle Campbell }}^{2,3,4}$
}

\begin{abstract}
Indigenous involvement in Australian water management is conventionally driven by a top-down approach by nonIndigenous government agencies, that asks "how do we engage Indigenous people?" and has culminated in the ineffective "consult" and "service delivery" processes evident in mainstream water management planning. This is a hopeful paper that identifies the critical importance of a "nation-based" approach for effective Indigenous engagement in water planning and policy through the work undertaken by the Ngarrindjeri Regional Authority (NRA) in the Murray Futures program. The NRA is an Indigenous government in the "settled-south" of Australia. Over past decades, the NRA has developed a range of political technologies that act as tools for redeveloping Ngarrindjeri Nationhood after colonial disempowerment and dispossession. These tools enable better collaboration with nonIndigenous governments, especially in natural resource management policy and practice. In turn, this has better enabled the NRA to exercise a decision-making and planning authority over the lands and waters in its jurisdiction, therefore, more effectively exercising its ongoing duty of care as Country. This paper presents a case study of the Sugar Shack Complex Management Plan, codeveloped by the NRA and the South Australian Government in 2015, to demonstrate the benefits that accrue when Indigenous nations are resourced as authorities responsible for reframing water management and planning approaches to facilitate the equitable collaboration of Indigenous and nonIndigenous worldviews. As a marker of the success of this strategy, the Ngarrindjeri Yarluwar-Ruwe Program, in partnership with the South Australian government, recently won the Australian Riverprize 2015 for delivering excellence in Australian river management.
\end{abstract}

Key Words: Decolonizing; Indigenous knowledge; Indigenous nation building; nation-based engagement; natural resource management; self-determination; water management; wetland planning

\section{NGARRINDJERI VISION FOR COUNTRY - KUNGUN NGARRINDJERI YUNNAN (Listen to what Ngarrindjeri people have to say) \\ Our Lands, Our Waters, Our People, All Living Things are connected. We implore people to respect our Ruwe (Country) as it was created in the Kaldowinyeri (the Creation). We long for sparkling, clean waters, healthy land and people and all living things. We long for the Yarluwar-Ruwe (Sea Country) of our ancestors. Our vision is all people Caring, Sharing, Knowing and Respecting the lands, the waters and all living things. Ngarrindjeri Nation in Murray-Darling Basin Authority (M-DBA) 2014:25.}

The Ngarrindjeri "Vision for Country" quoted above encapsulates the Ngarrindjeri philosophy of being (Ruwe/Ruwar) at the center of Ngarrindjeri innovations in water management. Its ancient but radical message has far-reaching implications for Australian water planning. Originally developed as part of the whole-of-country strategy expressed in the Ngarrindjeri Nation Yarluwar-Ruwe Plan (Ngarrindjeri Nation 2007), it asserts a sovereign vision for healthy Ngarrindjeri country, based on valuing Ngarrindjeri lifeways, values, and knowledge. Ngarrindjeri country is in the "settled south" of Australia, at the end of the iconic River Murray (Murrundi), the longest river in Australia and third longest navigable river in the world. Freshwater flows through the Murray-Darling system into Ngarrindjeri lands are, for Ngarrindjeri, the life blood of the living body of Murrundi. The mouth of the Murray and its nearby region is a place of great spiritual and cultural significance known and formally registered as the "Meeting of the Waters" where the salt and fresh waters mix. For Ngarrindjeri, the reproduction of wellbeing is inextricably linked to interconnectivity, estuarine mixing, and the overall health of Murrundi as a living body (see Simons 2003, Ngarrindjeri Nation 2007, Bell 2008, 2014, Hemming and Rigney 2008, Hemming 2009). Ngarrindjeri bring this understanding into all interactions with nonIndigenous natural resource management (NRM), and we argue that this, combined with an active Indigenous nation (re)building program, makes a vital contribution to improved river health.

The consequences of European invasion and the colonial exclusion of Indigenous peoples from citizenship and land ownership, and therefore from water rights, present complex challenges for restorative justice in Australia (see Morgan et al. 2004, Hemming et al. 2007, Bark et al. 2012, Tan and Jackson 2013). Indigenous water rights are an integral component of recognizing the inextricable links between people, land, and water. To contextualize our Ngarrindjeri case study, the first section of this paper outlines Australian water management policy contexts and aspirations and the limitations of these approaches for incorporating Indigenous values and interests. Australia did not formally recognize Indigenous interests in water policy until 2004, and they remain "an unmet demand on the water system" (National Water Commission (NWC) 2011:9). Since colonization, Ngarrindjeri have struggled for recognition and jurisdiction of Ngarrindjeri Yarluwar-Ruwe (Ngarrindjeri Country) and are yet to realize restorative justice in water resource management. The challenge for Ngarrindjeri continues to involve negotiating a just relationship with the settler-State based on recognition as a First Nation with an a priori responsibility to "Speak as Country" (Yannarumi). The Ngarrindjeri framework for integrated river management prioritizes First Nation capacity building and a sovereign responsibility to "Care as Country." As a consequence,

${ }^{1}$ Flinders University, ${ }^{2}$ Ngarrindjeri Regional Authority, ${ }^{3}$ Mannum Aboriginal Community Association Incorporated, ${ }^{4}$ Sugar Shack Aboriginal Corporation 
Ngarrindjeri emerged as authoritative partners to the South Australian government in successfully managing Murrundi through a period of unprecedented drought (see Hemming and Rigney 2012, Rigney et al. 2015, Cosens and Chaffin 2016).

This is a hopeful paper that recognizes Indigenous agency and leadership, in the form of nation (re)building, as an important emerging driver in water planning and management in Australia. We share the story of the Ngarrindjeri nation and describe the architecture of nation building that forms the foundations of this new form of Indigenous-led collaborative water management. Ngarrindjeri-led innovations, such as Yannarumi (Speaking as Country) health assessments, displace western forms of anthropocentrism and human exceptionalism (see Birckhead et al. 2011, Weir 2011, Bark et al. 2012, Jackson and Palmer 2012, Jackson et al. 2015, Rigney et al. 2015). We provide a case study of the development of Murrundi Recovery Sugar Shack Wetland Management Plan. This combines Indigenous philosophies and experiences of ongoing colonization with western science, to deliver an innovative management plan that meets what is conceived in western terms as "cultural" and "ecological" needs. The success of this work enabled Ngarrindjeri to broker the first Indigenous agreement with the Commonwealth Environmental Water Holder (CEWH) in Australia to use cultural priorities for the distribution of Commonwealth environmental water.

Taking a strong, sovereign approach to engaging with water planning in Australia has produced a healthier and more sustainable form of environmental management that is anchored in a long-standing Indigenous knowledge system and philosophy of being: Ngarrindjeri Yannarumi (Speaking as Country). This approach locates Ngarrindjeri as a political collective with its own knowledges and objectives and moves away from a simple service delivery model of Indigenous engagement. By acknowledging the Ngarrindjeri Nation as a political entity and not simply a cultural interest group, it resists the colonizing act of nonIndigenous authorities restricting Indigenous interests in water management to the cultural domain and thereby closing down consideration of Indigenous peoples' sovereign political rights to water. It shifts policy from the standard approach to engagement that denies Indigenous interests through short-term, crisis-driven, service delivery responses driven by external expectations and funding limitations, to a nation-building approach in which Ngarrindjeri are identifying, organizing, and acting as a nation and working strategically toward implementing priorities set by their own community (Cornell and Kalt 2007, Cornell 2015a, b, Rigney et al. 2015). In essence, this is "the practical exercise of de facto Indigenous sovereignty-irrespective of a constitutional recognition of de jure Indigenous sovereignty by a nonIndigenous system of law" (Rigney et al. 2015:343-344). The work undertaken by the Ngarrindjeri Regional Authority (NRA) in the Murray Futures program highlighted in this paper is testament to the critical importance of a nation-based approach to Indigenous engagement. Indigenous involvement in water management is conventionally driven by a top-down approach that asks "how do we engage Indigenous people?" and has culminated in the ineffective consultative and service delivery processes evident in mainstream water management planning. In contrast, we assert that Indigenous nations should be resourced as authorities responsible for reframing water management and planning approaches to facilitate the equitable collaboration of
Indigenous and nonIndigenous epistemologies and ontologies. As a marker of the success of this strategy, the Ngarrindjeri Yarluwar-Ruwe Program in partnership with the South Australian government recently won the Australian Riverprize 2015 for delivering excellence in Australian river management.

\section{INDIGENOUS ENGAGEMENT IN WATER MANAGEMENT IN AUSTRALIA}

Indigenous interests were placed on the agenda for water reform and management in Australia for the first time in 2004 as part of the National Water Initiative (NWI). The NWI and other policy shifts have seen a broadening of national water policy to include environmental, cultural, and social concerns, although these concerns are positioned within a "market environmentalism" framework (Godden and Gunther 2009:246) that relies on markets for water allocations (Jackson and Altman 2009). Jackson and Morrison (2007) argue that the NWI's ability to effectively address Indigenous interests and values is limited by the discretionary nature of the terms in the document (see also Tan and Jackson 2013), the lack of guidance for water resources planners and managers about how to engage Indigenous groups, and the inability to recognize Indigenous economic and commercial interests in water. Tan and Jackson (2013:138) also argue that State agencies have considered consultation "as more information-giving than active participation by communities." Planning agencies therefore do not incorporate or address Indigenous concerns and "rely on an outdated consultation paradigm that seeks to identify sites for heritage protection" (Tan and Jackson 2013:138). The NWC argues that the "cultural and economic expectations of Indigenous Australians [are] an unmet demand on the water system" (NWC 2011:9). Although we agree with these concerns, we are also critical of the ways in which critical water planning does not consider how Indigenous expectations are rarely simply cultural or economic, but also political in nature. The innovative and decolonial quality of the Ngarrindjeri intervention to water planning processes rests significantly on the Ngarrindjeri Regional Authority's efforts to reassert control over its jurisdiction by forming comanagement partnerships with NRM policy makers in government (Hemming and Rigney 2008). Nonetheless, the significance of this political intervention continues to be sidelined in the relevant critical literature, which accordingly misses the opportunity to observe how Ngarrindjeri already are addressing some of the limitations that have long plagued water planning and natural resource management programs in Australia. This section canvasses the literature that criticizes - at times obliquely - the standard assumption that Indigenous interests are cultural rather than political and can be accommodated by a form of engagement that does not extend decision-making authority to Indigenous agents. Following sections explain how the Ngarrindjeri Nation have transformed the nature of Indigenous engagement in water policy and planning by asserting its Indigenous authority in speaking as Country.

The Water Act 2007 sought to enact a new framework for collaboration between Basin States in Australia and reinforced the need to engage Indigenous groups in management. One of the significant features of the new arrangements was the development of the Commonwealth Environmental Water Holder (CEWH). The CEWH gives autonomy to the Commonwealth Government to purchase water entitlements, 
from willing sellers, to be used as a means of allocating water to the environment. These water entitlements are "permanently outside the consumptive pool" and are available for allocation even during times of severe drought (Connell 2011:336). Upon completion, the CEWH will "hold more than one quarter of all water entitlements in the MDB" (Connell 2011, 335). CEWH water is to be allocated to environmental priorities for river management. Many Indigenous communities in the MurrayDarling Basin (MDB) would like to see environmental water allocated to sites of cultural significance to their communities (Jackson et al. 2015), however, the decision making regarding the allocation of water remains vested in government. The Water Act 2007 also required the development of a whole-of-catchment Murray-Darling Basin Plan (MDBP), which was enacted in 2012. Under the Basin Plan, States are required to develop water resource plans in consultation with Indigenous groups, identifying Indigenous people's objectives and outcomes and having regard to their values and uses of water and their views on cultural flows; but, again, the authority for developing such plans remains vested in State governments. The Basin Plan requirements appear to go beyond the discretionary wording of the NWI, but the extent to which this process achieves meaningful change and brings benefits to Indigenous groups is yet to be seen.

Indigenous groups have expressed their desire to reverse past injustices of water dispossession through developing genuine partnerships in water management and for access to Indigenousspecific water allocations. One approach to recognizing Indigenous interests in water is for the establishment of Indigenous-specific water allocations or licences that can be used for commercial and customary purposes. Such water allocations have been referred to as "cultural flows" (Murray Lower Darling Rivers Indigenous Nations (MLDRIN) 2007 , Weir 2009, Weir et al. 2013) or "special Indigenous water allocations" (Tan and Jackson 2013:135), Indigenous water, Aboriginal water, native title water, cultural water, and others (Hemming et al. 2002, Hattam et al. 2007, Hemming and Rigney 2008, Birckhead et al. 2011, Weir et al. 2013:12-13). The MLDRIN define "cultural flows" as "water entitlements that are legally and beneficially owned by the Indigenous Nations of a sufficient and adequate quantity and quality to improve the spiritual, cultural, environmental, social and economic conditions of those Indigenous Nations" (MLDRIN 2007). A significant component of Indigenous-specific water rights is that Indigenous groups must have governance of the allocation of that water to meet Indigenous values, needs, and priorities (Weir et al. 2013), including economic purposes.

There is an ongoing assumption that Indigenous interests are limited to cultural values or heritage management (Jackson 2006) and a misplaced assumption that environmental water allocations will account for Indigenous values (Finn and Jackson 2011). Decisions about water are often thus made on ecological values alone. Significantly, this creates the risk of the denial of Indigenous agency and governance in managing water allocations with respect to Indigenous priorities (Weir et al. 2013:15). Weir and colleagues (2013:16) argue that "Indigenous people often identify Indigenous governance as a key distinction between environmental and cultural water. With cultural flows, it is the Indigenous peoples themselves who decide where and when water should be delivered, based on their priorities and goals." Many
Indigenous groups are keen to see water held by the CEWH used toward their own priorities, including roles for Indigenous governance, but not as a replacement of their a priori rights to water allocations (Jackson 2011, North Australian Indigenous Land and Sea Management Alliance (NAILSMA) 2012, Weir et al. 2013:27, Jackson et al. 2015). Jackson and Langton (2012) argue for a restorative justice initiative, in which governments should purchase water rights for Indigenous groups, in the same manner that they do for environmental use, through the CEWH. Indeed, the fact that "the environment" should be granted rights before Indigenous nations illustrates the lack of priority given to Indigenous water rights in the first place. In the absence of Indigenous-specific water allocations in South Australia, Indigenous groups assert their sovereign rights to speak as Country by seeking engagement in a range of other water management processes.

Representatives of the MLDRIN, like many other Indigenous groups, feel that their participation in water management is piecemeal and tokenistic as stakeholders on government committees (Godden and Gunther 2009:251). Ayre and Mackenzie (2013) demonstrate how water planning processes that seek to engage Indigenous people through performing cultural values studies, providing information, or consultation did not increase Indigenous people's participation, nor lead to the effective inclusion of Indigenous knowledges in planning. Rather engagement served to separate Indigenous so-called cultural insights and belief systems, leaving the scientific evidence to determine flow regimes. Intangible Indigenous values, vital to Indigenous ontology and epistemology, often challenge "the quantitative and competitive methods of resource allocation currently favoured by market-based reform programs" (Jackson 2011:171). Mainstream environmental and water planners struggle to recognize knowledges outside the "dominant ontological framing of Western science" (Ayre and Mackenzie 2013:759) and thus tend to dismiss Indigenous epistemologies and ontologies as merely cultural, excluding them from their management approaches (Jackson 2006, Hemming 2007, Hemming and Rigney 2008, Weir 2009, Jackson and Langton 2012, Muller 2012, 2014). Representing Indigenous views as cultural in water planning approaches does not guarantee equitable engagement (Hemming and Rigney 2008). If water planning approaches are only framed within the terms of dominant society, they will continue to perpetuate the marginalization of Indigenous nations.

Indigenous participants in water planning processes have an expectation of reciprocation of knowledge and resources (Muller 2012, Ayre and Mackenzie 2013). They seek opportunities for learning about western scientific approaches, developing their capacity to participate in and benefit from water planning processes, with concomitant employment opportunities (Ayre and Mackenzie 2013). They also require their partners in government and research to learn from Indigenous science, to be willing to take direction from Indigenous authorities in planning processes, and to cocreate relevant forms of employment. Government agencies are challenged to address their lack of awareness of how to recognize Indigenous values and interests (Jackson and Morrison 2007), including commercial rights and political authority (Hemming et al. 2011) in water resource management. These "capacity deficits" (see Howitt et al. 2013) 
on the part of government limit the potential for Indigenous groups to engage on their own terms.

A nation-building approach in which Indigenous nations are recognized as sovereign partners in water management and planning can serve to address many of the issues highlighted above (Hemming et al. 2011, Dolan et al. 2015). Indigenous Nations, adequately resourced, are able to build their own capacity to engage in the complexities of the rapidly evolving water management realm. Indigenous nations want to see an engagement across epistemologies and ontologies, the sharing of whole world views and institutional insights, rather than a oneway removal of Indigenous knowledge from its context and insertion of it into a mainstream framework (see Muller 2012, 2014). Engaging with Indigenous epistemologies and ontologies as the cultural anchors of Indigenous political authority can inherently change the overarching framework for natural resource management and provide new insight into sustainability (Berkes 1999, Armitage et al. 2010, Dolan et al. 2015, Rigney et al. 2015). The true opportunities and benefits of Indigenous participation in comanagement of lands and waters can only be realized if Indigenous nations are adequately resourced to be in the driving seat of incorporating their own knowledges in planning and management frameworks. Ngarrindjeri Nation engagement in water planning in South Australia provides a useful insight into the benefits of a nation-building approach for addressing the challenges of incorporating Indigenous values and interests into wetland management and environmental water allocation.

\section{FROM "FABRICATORS" TO INNOVATORS-THE NGARRINDJERI NATION-BUILDING APPROACH TO WATER MANAGEMENT}

In the early 1990s, the Ngarrindjeri Nation began a long campaign to protect the spiritual waters around Kumarangk (Hindmarsh Island) at the mouth of the River Murray. Ngarrindjeri elders and leaders argued that building a bridge between the mainland and the island would damage the spiritual and reproductive health of Ruwe/Ruwar (lands, waters, spirit, people and all living things) (Stevens 1995, Saunders 2003, Trevorrow and Hemming 2006, Bell 2008, 2014). South Australian cultural and natural resource management did not have the legislative or policy sophistication to understand or respect this Ngarrindjeri philosophy of being. The conflict was litigated in various courts, including a High Court case and a Royal Commission that controversially labeled Ngarrindjeri as "fabricators" of sacred women's traditions (Stevens 1995, Simons 2003, Hemming and Rigney 2008). The "bridge was built and the sacred passage between water and sky was blocked" (Rigney et al. 2015:336). In 2001, Justice von Doussa in the Federal Court of Australia found in favor of the Ngarrindjeri women's beliefs and traditions, and in 2010, the "Meeting of the Waters" was registered as a site under the Aboriginal Heritage Act, 1998 (SA) (von Doussa 2001, Hemming et al. 2011). The Kumarangk case exemplifies the ways in which the very existence of Indigenous nations in Australia's "settled south" challenge the authenticity of the settler-State, which seeks to define and contain their ongoing, creative relationships to country (including water) through past-oriented, cultural heritage management practices and neoliberal environmental management (Hemming 2007, Hemming and Rigney 2010, Tan and Jackson 2013). The devastation caused by the Kumarangk case inspired Ngarrindjeri leaders to develop new nation-building technologies and engagement mechanisms to renegotiate their interactions with the settler nation-state.

In the mid-1980s, Ngarrindjeri leaders and elders had decided to formally reestablish the traditional Tendi as a peak governing body. At the same time, local community organizations, such as the Ngarrindjeri Land and Progress Association, pioneered new forms of public pedagogy through the establishment of Camp Coorong: Race Relations and Cultural Education Centre (Hemming 1993). This ongoing process of sociopolitical realignment provided the context for the radical political shift that occurred formally in the early 2000s as drought took hold in the Murray-Darling Basin. Ngarrindjeri leaders and supporters decided to negotiate new relationships with the settler-State using contract law rather than relying upon legislation and policy drafted in line with colonial values. Key to this nation-building approach is the Kungun Ngarrindjeri Yunnan Agreement (KNYA) - Listen to Ngarrindjeri Speaking (KNYA 2009, Hemming et al. 2011, Rigney et al. 2015). The first KNYA was developed in 2002 with the Alexandrina Council (Hemming and Trevorrow 2005). Using contract law, the KNYA strategy aims "to shape and protect partnership agreements that acknowledge Ngarrindjeri cultural interests and social authority" (Rigney et al. 2015:340). The KNY process thereby provides a starting point for negotiations that recognize Ngarrindjeri sovereignty over their (unceded) territories (Rigney et al. 2015). Importantly, KNYAs provide Ngarrindjeri with a legal avenue for enforcing the terms of agreement-providing significantly greater protection of Indigenous interests compared with the consultation approaches that all too often renege on promises (Hemming et al. 2010). The KNY process provides a starting point for negotiations that require State recognition of Ngarrindjeri interests in lands and waters (Rigney et al. 2015). In 2002, Ngarrindjeri leaders coauthored a report on the implications of the closure of the River Murray mouth and argued that an agreement-making approach and support for Indigenous capacity building were required for just collaboration with Indigenous people in the Murray-Darling Basin (Hemming et al. 2002).

Stories of Ngarrindjeri cultural extinction in the face of British settlement continue to be recycled in contemporary NRM planning. Understanding the devastating impacts of this colonizing management regime, Ngarrindjeri developed a second, critical nation-building tool: the Ngarrindjeri Nation YarluwarRuwe Plan: Caring for Ngarrindjeri Sea Country and Culture (Ngarrindjeri Nation 2007). The Yarluwar-Ruwe Plan outlines the Ngarrindjeri vision for caring as country, emphasizing that "the river, lakes, wetlands/nurseries, Coorong estuary and sea have sustained us culturally and economically for tens of thousands of years" (Ngarrindjeri Nation 2007:6). The Plan "provides a strong statement of Ngarrindjeri rights, identity, authority and responsibility, ...[whilst] charting a vision for future, just collaborations between Ngarrindjeri and non-Indigenous institutions, governments, business and individuals" (Hemming and Rigney 2008:765). The Plan recommended the establishment of the Ngarrindjeri Caring for Country Centre to manage the implementation of the plan, which is now called the YarluwarRuwe Program. The release of the Yarluwar-Ruwe Plan coincided with the establishment of the Ngarrindjeri Regional Authority (NRA) as a peak regional organization to represent the Ngarrindjeri Nation, built upon a long history of Ngarrindjeri 
political organization and resistance to colonization (Rigney et al. 2015). The NRA aims to provide an effective and culturally appropriate governance structure enabling Ngarrindjeri to assert decision-making power and engage in long-term strategic approaches to issues such as water management, aimed at improving Ngarrindjeri wellbeing, rather than responding to short-term consultancy approaches that suit bureaucratic systems (Hemming and Rigney 2008). This moves beyond a fragmented service delivery model of Indigenous policy delivery, toward a self-determining, nation-building future based on Ngarrindjeri tradition, good governance, and a strong economy (see Cornell 2015a). In this way, Ngarrindjeri leaders serve as nation builders and mobilizers. The status quo of governments undertaking consultation with Ngarrindjeri in order to write their own reports to take back to government was not a relationship that worked for Ngarrindjeri. Indigenous Nation rebuilding aims to change the colonial relationship between the Ngarrindjeri nation and the settler-State to build Ngarrindjeri capacity to "Speak as Country" and to respect Ngarrindjeri knowledge, law, traditions, and experience. Recognizing the wider social benefits of this approach, the South Australian government has recently introduced a state-wide Aboriginal Regional Authority policy inspired by the success of the NRA (Department of State Development 2016).

The NRA now negotiates with government on a nation-to-nation basis to create policy that guarantees improved health for their country. For example, a KNYA was brokered in 2008 following disagreement between the Ngarrindjeri and the State about the construction of earthen bunds (the Goolwa Channel Regulators) that sought to maintain water levels in the Goolwa Channel and address the impacts of acid sulfate soil exposure. The agreement committed the State to the construction of temporary structures and methods aimed to minimize damage to the registered site, thus providing environmental health to the region, and the funding of an independent panel to determine when the regulators should be removed.

Subsequently, in 2009, after many months of negotiation a wholeof-government KNYA was brokered as an overarching agreement with the State that made a range of commitments to Ngarrindjeri, including resourcing of the NRA under the Murray Futures program. The South Australian Government's Murray Futures is a Commonwealth-funded program that seeks to address the impact of the Millennium Drought. There was a $\$ 600,000,000$ allocation to South Australia, which included the $\$ 137,000,000$ Coorong Lower Lakes and Murray Mouth (CLLMM) Recovery Project and the $\$ 98,000,000$ Riverine Recovery Project (RRP). The NRA renamed their involvement in the RRP project as the Murrundi (River Murray) Recovery Project (MRP) and have identified "Ngarrindjeri working together to bring life to Murrundi" as a key Ngarrindjeri objective. The KNYA 2009 also established a collaboration and negotiation framework between the parties in relation to natural resource and cultural heritage management. This includes regular leaders-to-leaders meetings between Ngarrindjeri leaders and government ministers; a KNYA joint taskforce creates a formal context for State government agencies to negotiate programs on Ngarrindjeri Ruwe/Ruwar (country/body/spirit) (see Department of Environment Water and Natural Resources and Ngarrindjeri Regional Authority 2016). Furthermore, the KNYA recognizes Ngarrindjeri traditional ownership and the NRA as the Ngarrindjeri peak body; and commits the State government to ensuring Ngarrindjeri cultural values become integral to all planning and management arrangements for lands and water. It also supports Ngarrindjeri gaining economic benefit and employment from the management of parks and reserves in their region. The whole-of-government KNYA 2009 has provided a political framework for an expanding set of innovations that support more just Indigenous engagement in environmental water planning in the South Australia MurrayDarling Basin (SAM-DB). The Taskforce enables integrated and coordinated collaboration between Ngarrindjeri and all levels of nonIndigenous government in the SAM-DB region. The relationship has also enabled Ngarrindjeri to provide guidance to government-led initiatives, and the establishment of new partnerships to further river basin integrated management. Importantly, the KNYA establishes a range of commitments outside of the realm of native title law; Ngarrindjeri have negotiated interests outside of the state-sponsored Indigenous Land Use Agreements (ILUA) (Rigney et al. 2008). This is significant at the national level, given that two of the NWI clauses related to Indigenous interests concern native title.

In 2009, under the umbrella of the KNYA, the Department for Environment, Water and Natural Resources (DEWNR) and the NRA codesigned the Ngarrindjeri Partnerships Project for the CLLMM Recovery Project. The Partnerships Project was aligned with, and designed to implement, the Indigenous nation-based solutions outlined in the Yarluwar-Ruwe Plan. The Partnerships Project focused on achieving Ngarrindjeri objectives for caring as Country. Importantly, it focused on funding the core organizational capacity of the NRA to support Ngarrindjeri to meet their customary rights and responsibilities to care as Country and to work with DEWNR on transforming regional natural resource management to support the long-term, resourced responsibilities for Ruwe/Ruwar. The Partnerships Project developed a range of innovative engagement approaches for water management, creating new and more equitable relationships. The State recognized Ngarrindjeri interests and cultural knowledge and committed to activities aligned with Ngarrindjeri objectives. The complex work of the Partnerships Project relied on the negotiation of cultural knowledge protection clauses in project agreements and a separate Cultural Knowledge Agreement for water planning between the state and the NRA (Hemming and Rigney 2010, 2014, Rigney et al. 2015). Another innovation was the Statement of Commitments, which are not legally binding, but articulate Ngarrindjeri interests, acknowledge Ngarrindjeri connection to Country, and agree to a set of engagement activities to achieve particular project objectives (DEWNR and NRA 2016). The 2014 Ngarrindjeri Speaking as Country Deed further commits the state and the NRA to working together to ensure freshwater flows down the river and promote and enhance the cultural and environmental values of the Meeting of the Waters. The resulting Ngarrindjeri Yarluwar-Ruwe Program provides a culturally appropriate and strategic mechanism for the facilitation of Ngarrindjeri engagement in the integrated management of Murrundi (River Murray), including partnerships in major regional NRM projects with the four regional NRM Boards and Local Councils in the Ngarrindjeri region. The Yarluwar-Ruwe Program is a key employer of Ngarrindjeri in the South Australian Murray-Darling Basin 
region, supporting Ngarrindjeri livelihoods through caring for Yarluwar-Ruwe. Ngarrindjeri engagement in Murray Futures and the Ngarrindjeri Partnerships Program and Yarluwar-Ruwe Program each represent an important shift from Ngarrindjeri being labeled cultural "fabricators" in the 1980s, to the recognition of the importance of Ngarrindjeri as partners in water management with concomitant funding enabling capacity building. This is an Indigenous-led pathway to engagement with the State (see Bignall 2010) that uses "key political technologies created by the Ngarrindjeri nation to enable its successful influence in matters affecting their country and community... firmly grounded in Ngarrindjeri ways of knowing, being and doing" (Rigney et al. 2015:335).

The Indigenous nation-building innovations outlined above are facilitating a growing Ngarrindjeri engagement with water planning and are providing unique solutions to the national challenge to find better ways for Indigenous people to form equitable partnerships in integrated river management on their Country. Highlighting these innovations demonstrates the value of a nation-building approach in which Ngarrindjeri have identified, organized, and acted as a nation to develop their own capacity to engage on more equitable nation-to-nation terms with the State (Cornell 2015a, Rigney et al. 2015, Cosens and Chaffin 2016). To further highlight the achievements noted here, the following section provides a case study to outline the Ngarrindjeri nation-building strategy applied to wetland planning. It documents the development and achievements of the Ngarrindjeri-led wetland planning at Sugar Shack Pangki on the River Murray and the associated arrangement with the CEWH for Ngarrindjeri to establish cultural priorities for environmental water allocations.

\section{A new approach to Indigenous-led wetland planning and environmental water allocations at Sugar Shack}

The Sugar Shack Complex is part of the living body of Murrundi (River Murray) and was created by Creation Ancestors such as Ngurunderi, Pondi (Murray Cod), and Thukabi (Macquarie Tortoise) and cared for by generations of Nganguraku and Ngaiawang, being part of the Ngarrindjeri Nation. For this wetland to continue to give life to Ngarrindjeri, it must be healthy and cared for in a culturally respectful manner. The initial inclusion of Ngarrindjeri knowledge and interests in this wetland plan is a preliminary step toward recognizing Ngarrindjeri understanding of the relationship between healthy lands and waters and all living things, and Ngarrindjeri responsibility for the overall health of the Sugar Shack Complex. Ngarrindjeri people - past, present, and future - are part of the living body of Murrundi.

Sugar Shack Pangki (wetland) complex is part of the living body of Murrundi (River Murray) and in 2013 it was nominated for inclusion by the NRA and its local member organisations in the Riverine Recovery Project (RRP). For Murrundi to continue to give life to Ngarrindjeri people it must be healthy and cared for in a culturally respected manner. Ngarrindjeri leaders saw opportunities for employment, training, collaborative water management and wetland management plan rewriting that would improve Ngarrindjeri Nation health and, therefore, the health of Murrundi. (NRA 2015:6)
From a western, natural science perspective, Sugar Shack is a floodplain complex of wetlands and anabranch creeks located on the lower River Murray, approximately $11 / 2 \mathrm{~h}$ northeast of Adelaide, immediately upstream of Swan Reach, South Australia (see Fig. 1). The complex is over 1000 ha and includes $10 \mathrm{~km}$ of river frontage and consists of 13 wetlands series. The complex is owned and managed by the Nganguraku, as part of the Ngarrindjeri Nation, through the Mannum Aboriginal Community Association Incorporated (MACAI) (a founding member of the NRA) and the Sugar Shack Aboriginal Corporation, with support from the NRA. The Ngarrindjeri/ Nganguraku in the Swan Reach area have been particularly subject to a colonial assumption of extinction, with influential texts declaring Aboriginal people in the area extinct as early as the 1850s (see Woods 1879, Hemming et al. 2000). These constructions of South Australian history helped exclude Ngarrindejri/Nganguraku from much of the key NRM planning in the region, with many of the wetland plans initially making no mention of Indigenous people. It is therefore hugely significant that the so-called "extinct" Ngarrindjeri/Nganguraku of this region are now leaders in Indigenous-led wetland planning. From the 1980s, leaders such as Colin Cook and Richard Hunter (both deceased) worked with their communities and institutions such as the South Australian Museum to record their histories of strong and continuing attachment to the mid-Murray region in South Australia (Hemming 1994). This work assisted younger generations of leaders in their engagement with the Murrundi Recovery Project (MRP).

Fig. 1. Sugar Shack Pangki.

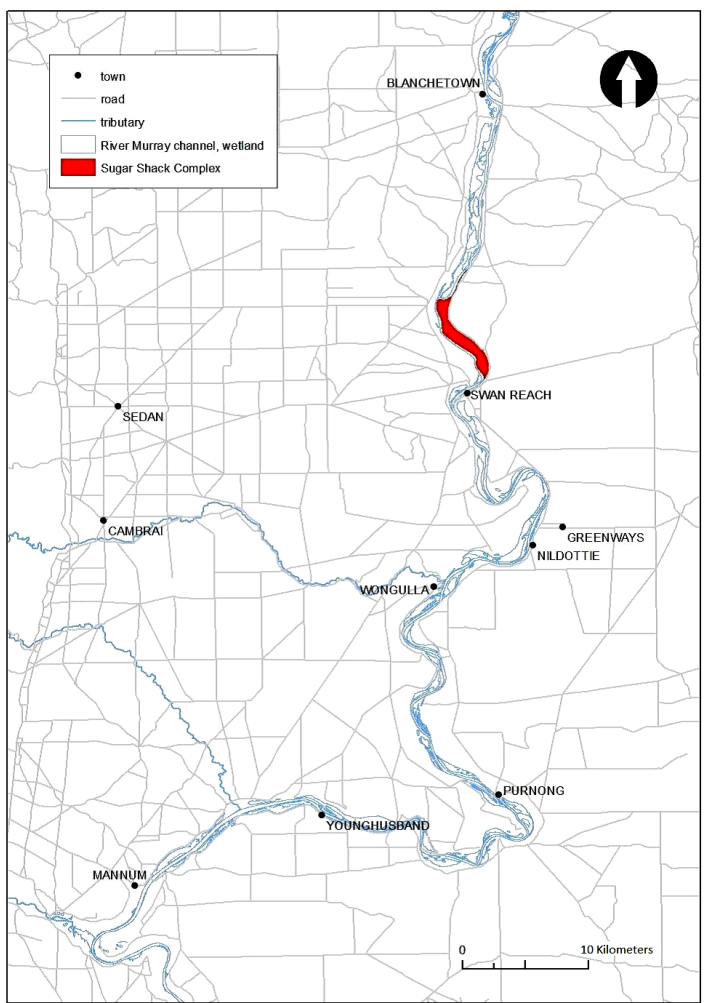


Within the Murray-Darling Basin, wetland management plans are required in order to change the water regimes of wetlands. At best, past wetland management plans developed by DEWNR for this region adopted the engagement and consultative approach critiqued in the literature above: they consulted with the Sugar Shack Aboriginal Corporation (SSAC) to incorporate their perspectives in the management plans, without also changing the management approach. In 2006, a wetland management plan was written for Sugar Shack wetland number 10 (Bjornsson 2006). The plan followed the standard NRM structure and approach, relegating assumed minimal Indigenous interests as cultural or archaeological with just three sentences on page one and two brief bullet points on page 2. In 2010, a "Cultural Water Study" was done at Sugar Shack (Mooney and Tan 2012). However, Ngarrindjeri/Nganguraku wanted to use an Indigenous-led, nation (re)building approach for wetland plan development and to author a wetland management plan for the entire Sugar Shack floodplain, at a landscape scale, that could effectively incorporate Ngarrindjeri/Nganguraku worldviews.

The NRA supported MACAI, as a key local organization, to engage in the broader MRP, employing two MACAI members to play leadership roles in the project. Heritage assessments for 18 wetlands were conducted and grounded in Ngarrindjeri values and philosophy, incorporating an assessment of the ongoing effects of colonization (Rigney et al. 2015). This included initial assessments at the concept design stages and follow-up heritage surveys, if required, during the detailed design phase. The NRA also conducted heritage assessments for groundwater well installation and geotechnical works and undertook monitoring during infrastructure works. Cultural awareness training for contractors and government workers was provided throughout the program. Additionally, a number of heritage training workshops were delivered to build technical skills in heritage management and cultural knowledge transmission. Importantly, NRA reviewed wetland management plans for each wetland nominated under the Riverine Recovery Program below the town of Morgan. These reviews involved a preliminary "Yannarumi" assessment of the health-giving capacity of these wetlands as part of the living body of Murrundi. Ensuring that ongoing assessment and monitoring takes place from the perspective of an Indigenous authority "Speaking as Country," this assessment includes issues such: Ngarrindjeri access; compliance with NRA agreements and protocols; local council and NRM Board planning and management practices; and breeding opportunities for Ngartjis (totems). To date, Ngarrindjeri input has been embedded into 25 plans in the region, and Ngarrindjeri are also seeking wetland registration under the Aboriginal Heritage Act 1988 (SA). As part of the review process of these plans, the NRA decided that they wanted to rewrite the plan for the Sugar Shack wetland 10 themselves.

In mid-2013, the NRA seconded a DEWNR ecologist to be outposted to their organization for 9 mo to work alongside the NRA to codevelop the Sugar Shack Pangki wetland management plan and to expand the plan from wetland 10 to include the whole complex. The ecologist and NRA representatives made field trips together and ran group workshops to talk about wetland ecology and works and measures options for improving wetland management. MACAI representatives decided which wetlands would be included in the plan and set the vision for the wetland management plan-to see, as far as possible, "the flows the ancestors would have seen" (NRA 2015). Wetland planning normally uses an approach that focuses on the management of threatened or economically important species and developing wetting and drying regimes to address those species needs using an artificial hydrograph. However, given the NRA's vision for managing the wetland according to what the ancestors would have seen, the DEWNR ecologist innovatively used "hindcasting" models that look back on records to model preregulation water flows as much as possible by using the recorded data over the last 100 years for the location and heights of wetlands (Robinson 2013). In essence, this aimed to develop flow models that would be as close as possible to what the ancestors would have experienced and recreate preregulation wetting and drying regimes. These models provided a first step, the framework for the plan, and the planning partners then worked to further refine the management plan. There were a range of community aspirations for how to manage the wetland, and the ecologist also worked to include an ecological perspective in the planning. The process enabled Ngarrindjeri to develop awareness of how management plans are produced, and the team worked together to ensure that NRA visions and aspirations were included throughout the development of the whole plan-rather than tacking a "cultural" chapter onto a mainstream wetland management plan. This approach enabled a shift from the involvement phase, in which the NRA were monitoring an external planning agency, to a stronger collaborative partnership in which the NRA were codevelopers of the plan (cf Nursey-Bray and Arabana Aboriginal Corporation 2015). The MACAI also made decisions about where they wanted structures placed to manage the wetlands.

This process is preliminary and ongoing and stands as a crucial first step in embedding Ngarrindjeri interests into wetland management planning in the region. The codeveloped Sugar Shack Complex Management Plan 2015 (NRA 2015) begins the process that privileges cultural knowledges, Ngarrindjeri/ Nganguraku aspirations, and a Ngarrindjeri/ Nganguraku understanding of the relationship between healthy lands and waters and all living things in the long-term management of this significant wetland complex, while incorporating western scientific knowledge. Although the plan still reflects a nonIndigenous perspective, as the NRA develops more experience with wetland planning and a healthier future for the Sugar Shack complex, the wetland management plan will become increasingly Ngarrindjeri/Nganguraku focused. In future, this planning process will seek to incorporate the best Ngarrindjeri and nonNgarrindjeri science and continue to build strong partnerships between Ngarrindjeri and nonNgarrindjeri organizations, becoming an example of best practice Indigenous management of wetlands in the Murray-Darling Basin. Importantly, this project demonstrates a specific example of including Indigenous agency to safeguard values and uses in water and wetland planning.

The experience and understanding of water management developed by NRA and its member organizations through the partnerships outlined above has enabled the NRA to develop a water delivery agreement with the CEWH. Over the next few years, the NRA will develop watering proposals for their Country to submit to the CEWH. As such, the NRA can identify what 
they want to prioritize and will use Ngarrindjeri knowledge to deliver environmental water according to cultural values. Significantly, this is the first Commonwealth agreement for delivering environmental water based on Indigenous cultural priorities that has been developed with an Indigenous organization in Australia. This work is solely funded by NRA.

\section{CONCLUSION}

Without treaties and water rights, Indigenous nations in Australia are compelled to think creatively to negotiate just relationships with the settler-State to exercise their responsibility to care as Country (Pert et al. 2014). This creativity involves research, political negotiation, partnership building, education, and the rewriting of the NRM legislative and policy landscape. A new approach to Australian water management is emerging that supports Indigenous nation building and ensures that Indigenous engagement is not done on an ad hoc basis, selectively choosing individuals from communities to respond to government-led initiatives. Rather, a nation-to-nation approach enables Indigenous polities to build their capacity to partner with nonIndigenous government agencies in the development of environmental initiatives and, critically, to ensure that their nations can construct strategic and long-term partnerships, based on their own aspirations and the health of Country. We argue that the nation-building approach, illustrated in the Ngarrindjeri political architecture outlined above and demonstrated in practice through the Ngarrindjeri Partnerships Project, the Murrundi Recovery Project, and the Sugar Shack case study, is an appropriate means of enabling Indigenous groups to ensure that the processes of their engagement result in their ontologies and epistemologies being respected as authoritative. This paper explains how NRA involvement in the Murray Futures program has enabled Ngarrindjeri to continue to exercise their rights and responsibility to Ruwe/Ruwar through direct negotiations with government project managers, contractors, and landholders. The program has developed Ngarrindjeri understanding of NRM and water and wetland planning. It also strengthens the partnership between the NRA and the South Australia government in NRM by providing further clarity in relation to effective Indigenous engagement in water planning. This has direct benefits for the river, and thus for all Australians.

Ultimately, the Murrundi Recovery Sugar Shack Complex Management Plan 2015 highlights the opportunities that can come from an Indigenous nation-building approach to water management in Australia. The Plan was developed using an Ngarrindjeri/Nganguraku vision for the wetland complex, enabling an alternative basis for modeling and new strategies for protecting and enhancing cultural values and the use of the wetland. The project saw a much stronger role for Ngarrindjeri/ Nganguraku in development and management, including opportunities to be involved in the operation and maintenance of infrastructure and delivery of wetland monitoring programs in partnership with regional NRM bodies. It takes a significant step toward better reflecting Indigenous priorities in wetland management planning, which therefore are not reduced in this case to aspirations and an "impossible dreaming" (Tan and Jackson 2013). Importantly, the increased capacity for the community to be in control of management decisions has led to the brokering of a new water delivery agreement with the Commonwealth Government, the first one with an Indigenous organization in Australia. This achievement would not be possible without the nation-building approach outlined above. Finally, it is important to reflect on the fact that the exact same cultural knowledge that was dismissed as a fabrication in the most horrifically public way during Kumarangk, is now the keystone of an important, innovative, and leading approach to appropriate comanagement of water resources. From a baseline state of disempowerment characterized by their treatment during the traumatic Hindmarsh Island Bridge controversy in the 1990s, Ngarrindjeri have emerged as critical partners with the South Australian Government in managing the River Murray.

Responses to this article can be read online at: http://www.ecologyandsociety.org/issues/responses. $\mathrm{php} / 8982$

\section{Acknowledgments:}

The authors acknowledge the Ngarrindjeri Regional Authority Yarluwar-Ruwe program and Murrundi Recovery Project team for their work on the projects described in this paper. Thanks in particular to our colleague Simone Bignall for her editorial advice on this paper, to Lachlan Sutherland for his untiring, creative work on the Murray Futures projects as Aboriginal Partnerships Coordinator DEWNR, and to Shaun Berg for his contributions as Ngarrindjeri legal advisor and colleague. The authors also acknowledge the contributions of Amy Della-Sale, Stephen Jenkins, Luke Trevorrow, Tom Trevorrow (deceased), Rick Hartman, Ivy Campbell, Anita Hunter, Sam Stewart, Clyde Rigney, Jr., Ben Taylor (DEWNR Ecologist), and Michael Diplock. This article was produced with support from the Australian Research Council for projects titled: "Negotiating a space in the nation: the case of Ngarrindjeri" (DP1094869); and "Indigenous nationhood in the absence of recognition: self-governance insights and strategies from three Aboriginal communities" (LP140100376). Additional support was provided by the Melbourne School of Government Indigenous Nation-Building project and the Goyder Institute for Water Research. The NRA Yarluwar-Ruwe program has received substantial support from the CLLMM Ngarrindjeri Partnership Project and Riverine (Murrundi) Recovery Project-components of the South Australian Government's Murray Futures program funded by the Australian Government's Water for the Future initiative. The authors thank the Ngarrindjeri Regional Authority; the South Australian Department for Water and Natural Resources; the Australian Government Department for the Environment; Berg Lawyers; the Office of Indigenous Strategy and Engagement, Flinders University; Jumbunna Indigenous House of Learning, UTS; the Native Nations Institute, University of Arizona, and all the research partners involved in Ngarrindjeri nation building and Caring as Country programs. In particular, the authors thank our colleagues Professor Larissa Behrendt, Professor Stephen Cornell, Robert Hattam, Professor Miriam Jorgenson, Alison Vivian, Mark McMillan, Peter Bishop, Professor Robin Boast, Belinda McGill, and Julie Matthews and all our research partners. We acknowledge the intellectual work of past and present Ngarrindjeri leaders and Elders who have consistently and courageously applied Ngarrindjeri values to engagements with government agencies concerning Ngarrindjeri Yarluwar-Ruwe. Finally, we would pay our respects to 
the leadership of George Trevorrow (Rupelli), Matthew Rigney, Tom Trevorrow, Richard Hunter, and Colin Cook (all deceased).

\section{LITERATURE CITED}

Armitage, D., F. Berkes, and N. Doubleday. 2010. Adaptive comanagement: collaboration, learning and multi-level governance. University of British Columbia Press, Vancouver, British Columbia, Canada.

Ayre, M., and J. Mackenzie. 2013. "Unwritten, unsaid, just known": the role of Indigenous knowledge(s) in water planning in Australia. Local Environment 18(7): 753-768.

Bark, R. H., D. E. Garrick, C. J. Robinson, and S. Jackson. 2012. Adaptive basin governance and the prospects for meeting Indigenous water claims. Environmental Science and Policy 1920: 169-177. http://dx.doi.org/10.1016/j.envsci.2012.03.005

Bell, D. 2008. Kungun Ngarrindjeri Miminar Yunnan: listen to Ngarrindjeri women speaking. Spinifex, North Melbourne, Australia.

Bell, D. 2014. Ngarrindjeri Wurruwarrin: a world that is, was and will be. Spinifex, North Melbourne, Australia.

Berkes, F. 1999. Sacred ecology: traditional ecological knowledge and resource management. Taylor and Francis, Philadelphia, Pennsylvania, USA.

Bignall, S. 2010. Postcolonial agency: critique and constructivism. Edinburgh University Press, Edinburgh, UK. http://dx.doi. org/10.3366/edinburgh/9780748639434.001.0001

Birckhead, J., R. Greiner, S. Hemming, D. Rigney, M. Rigney, G. Trevorrow, and T. Trevorrow. 2011. Economic and cultural values of water to the Ngarrindjeri people of the Lower Lakes, Coorong and Murray Mouth. Townsville, CSIRO Water-For-A-HealthyCountry Flagship Report, River Consulting, Townsville, Queensland, Australia.

Bjornsson, K. T. 2006. Sugar Shack lagoon wetland management plan. Mid Murray Local Action Planning Committee, Cambrai, South Australia, Australia.

Connell, D. 2011. The role of the Commonwealth Environmental Water Holder. Pages 327-338 in D. Connell and R. Q. Grafton. Basin futures: water reform in the Murray-Darling Basin. ANU Press, Canberra, Australia.

Cornell, S. 2015a. Processes of Native nationhood: the Indigenous politics of self-government. International Indigenous Policy Journal 6(4): 4. DOI: 10.18584/iipj.12015.18586.18584.18584. http://dx.doi.org/10.18584/iipj.12015.18586.18584.18584.

Cornell, S. 2015b. "Wolves have a constitution": continuities in Indigenous self-government. International Indigenous Policy Journal 6(1): 8. DOI: 10.18584/iipj.12015.18586.18581.18588. http://dx.doi.org/10.18584/iipj.12015.18586.18581.18588.

Cornell, S., and J. P. Kalt. 2007. Two approaches to the development of Native nations: one works, the other doesn't. Pages 3-33 in M. Jorgensen. Native nations: srategies for governance and development. University of Arizona Press, Tucson, Arizona, USA.
Cosens, B., and B. C. Chaffin. 2016. Adaptive governance of water resources shared with Indigenous peoples: the role of law. Water 8(3): 97. http://dx.doi.org/10.3390/w8030097

Department of Environment Water and Natural Resources (DEWNR) and Ngarrindjeri Regional Authority (NRA). 2016. Kungun Ngarrindjeri Yunnan Agreement. Listening to Ngarrindjeri People Talking. KNYA Taskforce Report 2014-2015. [online] URL: https://www.environment.sa.gov.au/files/.../public/.../knyataskforce-2014-15-rep.pdf.

Department of State Development. 2016. South Australian Aboriginal Regional Authority policy: a regional approach to Aboriginal governance in South Australia. [online] URL: $\underline{\text { http:// }}$ www.statedevelopment.sa.gov.au/upload/aard/ara/ara-policy.pdf? $\mathrm{t}=1476227665916$.

Dolan, J., I. Record, M. Jorgensen, and E. Briggs. 2015. Honoring nations all-stars profile: the Red Lake walleye recovery program Red Lake Nation. [online] URL: http://hpaied.org/sites/default/ files/publications $/$ Red $\% 20$ Lake $\%$ 20Profile.pdf.

Finn, M., and S. Jackson. 2011. Protecting Indigenous values in water management: a challenge to conventional environmental flow assessments. Ecosystems 14: 1232-1248. http://dx.doi. org/10.1007/s10021-011-9476-0

Godden, L., and M. Gunther. 2009. Realising capacity: Indigenous involvement in water law and policy reform in southeastern Australia. Journal of Water Law 20: 243-253.

Hattam, R., D. Rigney, and S. Hemming. 2007. Reconciliation?: culture, nature and the Murray River. Pages 105-122 in E. M. Potter, A. MacKinnon, S. McKenzie, and J. McKay, editors. Fresh water: new perspectives on water in Australia. Melbourne University Press, Carleton, Victoria, Australia.

Hemming, S. 1993 Camp Coorong-combining race relations and cultural education. Social Alternatives 12(1): 37-40.

Hemming, S. J. 1994. In the tracks of Ngurunderi: the South Australian Museum's Ngurunderi exhibition and cultural tourism. Australian Aboriginal Studies 2: 38-46.

Hemming, S. 2007. Managing cultures into the past. Pages 150167 in D. W. Riggs. Taking up the challenge: critical race and whiteness studies in a postcolonising nation. Crawford House Publishing, Belair, South Australia.

Hemming, S. 2009. Ngarrindjeri cultural heritage management, colonial misuse of water, climate change, and planning for a future. Heritage Management 2(2): 252-255. http://dx.doi.org/ https://doi.org/10.1179/hma.2009.2.2.252

Hemming, S., and D. Rigney. 2008. Unsettling sustainability: ngarrindjeri political literacies, strategies of engagement and transformation. Continuum 22(6): 757-775. http://dx.doi. org/10.1080/10304310802452438

Hemming, S., and D. Rigney. 2010. Researching on Ngarrindjeri Ruwe/Ruwar: methodologies for positive transformation. Australian Aboriginal Studies 2: 92-106.

Hemming, S., and D. Rigney. 2012. Ngarrindjeri futures: negotiating a future through caring for Ruwe/Ruwar (lands, 
waters and all living things). Pages 186-191 in P. Figgis, J. Fitzsimons, and J. Irving. Innovation for 21st Century Conservation. Australian Committee for IUCN, Syndey, Australia.

Hemming, S., and D. Rigney. 2014. Indigenous engagement in environmental water planning, research and management: innovations in South Australia's Murray-Darling Basin Region. Adelaide, South Australia. Goyder Institute for Water Research, Technical Report Series No. 14/21, Adelaide, Australia.

Hemming, S., D. Rigney, and S. Berg. 2010. Researching on Ngarrindjeri Ruwe/Ruwar: methodologies for positive transformation. Australian Aboriginal Studies 2: 92-106.

Hemming, S., D. Rigney, and S. Berg. 2011. Ngarrindjeri futures: negotiation, governance and environmental management. Pages 98-113 in S. Maddison and M. Briggs. Unsettling the settler state. Federation Press, Annandale, New South Wales, Australia.

Hemming, S., D. Rigney, and M. Pearce. 2007. Justice, culture and economy for the Ngarrindjeri nation. Pages 217-233 in E. Potter, S. McKenzie, A. Mackinnon, and J. McKay. Fresh water: new perspectives on water in Australia. Melbourne University Press, Melbourne, Australia.

Hemming, S., and T. Trevorrow. 2005. Kungun Ngarrindjeri Yunnan: archaeology, colonialism and re-claiming the future. Pages 243-261 in C. Smith and H. Martin Wobst, editors. Indigenous archaeologies: decolonising theory and practice. Routledge, London, UK.

Hemming, S., G. Trevorrow, and M. Rigney. 2002. Ngarrindjeri culture. Pages 12-19 in M. Goodwin and S. Bennett. The Murray Mouth: exploring the implications of closure or restricted flow. Department of Water, Land and Biodiversity Conservation, Adelaide, Australia.

Hemming, S., V. Wood, and R. Hunter. 2000. Researching the past: oral history and archaeology at Swan Reach. Pages 331-359 in R. Torrens and A. Clarke. The archaeology of difference: negotiating cross-cultural engagements in Oceania. Routledge, London, UK.

Howitt, R., K. Doohan, S. Suchet-Pearson, G. Lunkapis, S. Muller, R. Lawrence, S. Prout, S. Veland, and S. Cross. 2013. Capacity decifits at cultural interfaces of land and sea management. Pages 313-358 in R. Walker, T. Jojola, and D. Natcher. Reclaiming indigenous planning. McGill-Queens University Press, Toronto, Ontario, Canada.

Jackson, S. E. 2006 Compartmentalising culture: the articulation and consideration of Indigenous values in water resource management. Australian Geographer 37(1): 19-31. http://dx.doi. org/https://doi.org/10.1080/00049180500511947

Jackson, S. 2011. Indigenous water management: priorities for the next five years. Pages 163-178 in D. Connell and R. Q. Grafton, editors. Basin futures: water reform in the MurrayDarling Basin. ANU Press, Canberra, Australia.

Jackson, S., and J. Altman. 2009. Indigenous rights and water policy: perspectives from tropical northern Australia. Australian Indigenous Law Review 13(1): 27-48.
Jackson, S., and M. Langton. 2012. Trends in the recognition of Indigenous water needs in Australian water reform: the limitations of "cultural" entitlements in achieving water equity. Journal of Water Law 22: 109-123.

Jackson, S., and J. Morrison. 2007. Indigenous perspectives in water management, reforms and implementation. Pages 23-42 in K. Hussey and S. Dovers. Managing water for Australia: the social and institutional challenges. CSIRO Publishing, Victoria, Australia.

Jackson, S., and L. Palmer. 2012. Modernising water: articulating custom in water governance in Australia and East Timor. The International Indigenous Policy Journal 3(3): 1-25. http://dx.doi. org/https://doi.org/10.18584/iipj.2012.3.3.7

Jackson, S., C. Pollino, K. Maclean, R. H. Bark, and B, Moggridge. 2015. Meeting Indigenous peoples' objectives in environmental flow assessments: case studies from an Australian multi-jurisdictional water sharing initiative. Journal of Hyrdology 522: 141-151. http://dx.doi.org/10.1016/j.jhydrol.2014.12.047

Kungun Ngarrindjeri Yunnan Agreement (KNYA). 2009. Ngarrindjeri Tendi Incorporated, Ngarrindjeri Heritage Committee Incorporated and Ngarrindjeri Native Title Management Committee for and on behalf of the Ngarrindjeri people and The Crown in right of the State of South Australia represented by the Minister for Environment and Conservation, the Minister for Aboriginal Affairs and Reconciliation, the Minister for the River Murray, and the Minister for Agriculture, Food and Fisheries (5 June 2009).

Mooney, C., and P.-L. Tan. 2012. South Australia-s River Murry: social and cultural values in water planning. Journal of Hydrology 474: 29-37. http://dx.doi.org/https://doi.org/10.1016/j.jhydrol.2012.04.010

Morgan, M., L. Strelein, and J. Weir. 2004. Indigenous rights to water in the Murray Darling Basin. In support of the Indigenous final report to the Living Murray initiative. AIATSIS Reserach Discussion Paper, Canberra, Australia.

Muller, S. 2012. Two ways: bringing Indigenous and nonIndigenous knowledges together. Pages 59-79 in J. Weir. Country, native title and ecology. ANU ePress, Canberra, Australia.

Muller, S. L. 2014. Co-motion: making space to care for country. Geoforum 54: 132-141. http://dx.doi.org/10.1016/j.geoforum.2014.04.011

Murray-Darling Basin Authority (M-DBA). 2014. Lower Lakes, Coorong and Murray Mouth environmental water management plan. Murray-Darling Basin Authority, Canberra, Australia.

Murray Lower Darling Rivers Indigenous Nations (MLDRIN). 2007. A cooperative agreement between Murray Lower Darling Rivers Indigenous Nations and environmental non-government organisations, 23 February 2007.

National Water Commission (NWC). 2011. The National Water Initiative-securing Australia's water future 2011 assessmnent. NWC, Canberra, Australia.

Ngarrindjeri Nation. 2007. Ngarrindjeri Nation Yarluwar-Ruwe plan. Caring for Ngarrindjeri sea country and culture. Ngarrindjeri Regional Authority, Murray Bridge, Australia. 
Ngarrindjeri Regional Authority (NRA). 2015. Sugar Shack complex management plan. Ngarrindjeri Regional Authority, Murray Bridge, Australia.

North Australian Indigenous Land and Sea Management Alliance (NAILSMA). 2012. Indigenous people's right to the commercial use and management of water on their traditional territories. An Indigenous water policy position on the Strategic Indigenous Reserve. NAILSMA Indigenous Water Policy Group. NAILSMA, Darwin, Australia.

Nursey-Bray and Arabana Aboriginal Corporation. 2015. Cultural indicators, country and culture: the Arabana, change and water. The Rangeland Journal 37: 555-569.

Pert, P. L., R. Hill, K. Maclean, A. Dale, P. Rist, J. Schmider, L. Talbot, and L. Tawake. 2014 Mapping cultural ecosystem services with rainforest aboriginal peoples: integrating biocultural diversity, governance and social variation. Ecosystem Services 13: 41-56. http://dx.doi.org/https://doi.org/10.1016/j.ecoser.2014.10.012

Rigney, D., S. Bignall, and S. Hemming. 2015. Negotiating Indigenous modernity. Kungun Ngarrindjeri Yunnan-listen to Ngarrindjeri speak. Alternative 11(4): 334-349. http://dx.doi.org/ https://doi.org/10.1177/117718011501100402

Rigney, D., S. Hemming, and S. Berg. 2008. Letters patent, native title and the Crown in South Australia. Pages 161-178 in M. Hinton, D. Rigney, and E. Johnston. Indigenous Australians and the law. Routledge-Cavendish, London, UK; New York, New York, USA.

Robinson, S. 2013. Statistical description of wetland hydrological connectivity to the River Murray in South Australia under both natural and regulated conditions. Report submitted to the Government of South Australia Department of Environment, Water and Natural Resources. University of Adelaide, Adelaide, Australia. http://dx.doi.org/10.1016/j.jhydrol.2015.10.006

Saunders, S. 2003 Are they going to pull it down? Overland 171: 60-62.

Simons, M. 2003. The meeting of the waters. Hodder Headline, Sydney, Australia.

Stevens, I. 1995. Report of the Hindmarsh Island Bridge Royal Commission. Government of South Australia, Adelaide, Australia.

Tan, P.-L., and S. Jackson. 2013. Impossible dreaming - does Australia's wter law and policy fulfill Indigenous aspirations? Environmental and Planning Law Journal 30: 132-149.

Trevorrow, T., and S. Hemming. 2006. Conversation: Kungun Ngarrindjeri Yunnan-listen to Ngarrindjeri People Talking. Pages 295-304 in G. Worby and L.-I. Rigney. Sharing spaces: Indigenous and non-Indigenous responses to story, country and rights. API Network, Perth, Australia.

von Doussa, J. 2001. Chapmans vs. Luminis and Ors, Federal Court of Australia, Summary of Judgement 21 August 2001.

Weir, J. 2011. Water planning and dispossession. Pages 179-191 in D. Connel and Q. Grafton. Basin futures: water reform in the Murray-Darling Basin. ANU ePress, Canberra, Australia. [online] URL: http://press.anu.edu.au/publications/basin-futures.
Weir, J. K. 2009. Murray River country: an ecological dialogue with traditional owners. Aboriginal Studies Press, Canberra, Australia.

Weir, J. K., S. L. Ross, D. R. J. Crew, and J. L. Crew. 2013. Cultural water and the Edward/Kolety and Wakool river system. Research report. AIATSIS Centre for Land and Water Research, Australian Institution of Aboriginal and Torres Strait Islander Studies, Canberra, Australia.

Woods, J. D., editor. 1879. The Native tribes of South Australia Adelaide. E. S. Wigg and Son, Adelaide, Australia. 